\title{
RELACIONES ARTÍSTICAS TRANSFRONTERIZAS. LA ACTIVIDAD DE LOS CANTEROS GALLEGOS EN LA CUENCA DEL LIMA/LIMIA EN LA ÉPOCA MODERNA
}

Data recepción: 2010/03/30

Data aceptación: 2010/04/21

Contacto autora: paula.cardona.pt@gmail.com

\author{
Paula Cristina Machado Cardona \\ Centro de Estudos da Economía, População \\ e Sociedade da Universidade do Porto
}

\section{RESUMEN}

La región de Galicia asume una considerable expresión en la presencia y permanencia de maestros canteros en el norte de Portugal. La proximidad geográfica y las históricas relaciones comerciales y culturales son razones de peso que justifican, de forma más global, el gran flujo de artistas gallegos en dirección a la cuenca del Lima.

Observando el panorama general de las obras ejecutadas por artistas y artífices gallegos en la región de Lima es possible constatar, que gran parte de las obras que absorbían mano de obra gallega eran de carácter arquitectónico y dentro de esta categoría, las que más abundaban eran las religiosas, aunque, en casos puntuales, maestros canteros gallegos son contratados para ejecutar obras de arquitectura civil. No obstante, aún se mantienen muchas preguntas en torno a la investigación que está por hacer, en el sentido de descubrir de forma más precisa la expresión, dimensión e influencia de estos artistas por toda la región del Norte de Portugal.

Palabras clave: Galicia, maestros canteros, obras, región del Lima

\section{ABSTRACT}

A sizeable number of master masons working in the north of Portugal hailed from the region of Galicia. Geographical proximity and long-established trade and cultural links are the main reasons behind the significant influx of Galician artists to the Lima Basin.

A general overview of the work carried out by Galician artists and craftsmen in the Lima region shows that a significant part of it was architectural in nature, most of it ecclesiastical, although Galician master masons were occasionally given secular commissions.

However, much research still needs to be carried out in order to gain a more accurate picture of the expression, dimension and influence of these artists across northern Portugal as a whole.

Keywords: Galicia, master masons, works, region of Lima

Son diversos los factores que, con permanencia y continuidad, subyacen en un territorio separado por dos naciones. De entre esos factores, el geográfico se impone como el de mayor impronta, aunque a esta característica deba añadirse el origen lingüístico, cultural y quizá, en una época determinada, el artístico. Estamos hablando del noroeste peninsular y de su peculiaridad en cuanto a la identidad en el contexto de los dos países de Iberia, Portugal y España.

Estas particularidades que aproximan el territorio Minho-Lima a Galicia y viceversa se unen en un núcleo común marcado por proce- sos de fragmentación y convergencias que la historia explica y al que la voluntad de los hombres otorgó atributos distintivos que permanecen en estas dos comunidades.

La matriz común constituye un tema cerrado, la construcción de las fronteras políticas, eclesiásticas y administrativas no restringió los intercambios económicos de origen comercial, los movimientos migratorios con base social y los intercambios culturales. La región GaliciaPortugal, en concreto el Norte, se presentó siempre como contigüidad geográfica y territorio económico común, que compartía el mismo 
origen histórico, la misma base cultural y la misma estructura léxica.

Los territorios atlánticos del Norte de Portugal siempre han mantenido, incluso tras la definición de las fronteras y las fragmentaciones políticas y religiosas, relaciones mercantiles con la vecina Galicia, como atestigua el caso concreto de Viana do Castelo, más desarrollada económicamente que los demás municipios portugueses de los valles del Minho y el Lima, que mantendrá de forma estructurada, desde la Edad Media, relaciones comerciales con el territorio gallego. Estos contactos eran esencialmente marítimos, las flotas vianenses navegaban regularmente por la costa de Galicia y Vizcaya, y de su puerto de mar partía todo tipo de productos hacia Galicia. Estas relaciones, de base económica, resultan más que patentes los siglos posteriores, apoyadas en mecanismos de carácter administrativo que demostraban, al mismo tiempo, la importancia de los contactos que al más diverso nivel se establecían con las provincias gallegas y con el reino de Vizcaya. Nos referimos a los instrumentos de carácter administrativo, documentados en el archivo Municipal de Viana do Castelo, referentes al gobierno y a la gestión local, relacionados, por un lado, con medidas reglamentarias de protección mercantil — de la cual es ejemplo, en 1719, la puesta en práctica de restricciones dirigidas a la flotas gallegas y vizcaínas que prohibían la comercialización de plata y oro por escasear en Viana do Castelo' - y, por otro lado, la existencia de un cuerpo de oficiales municipales con función de traductores, que en algunos casos sumaban funciones consulares, denominado «Partido de las lenguas»: en esencia, eran cargos de nombramiento municipal, ejercidos por un periodo de tres años, ocupados por ciudadanos nacionales o extranjeros residentes en Viana y con nombramiento para uno o más partidos, dependiendo de su capacitación lingüística en el idioma extranjero. En la segunda mitad del siglo XVII Domingos Soares recibe el nombramiento municipal para ejercer el partido de la lengua de los vizcaínos, castellanos y gallegos; a su fallecimiento en 1680 es sustituido por João Pereira de Castro, al que sucede, en 1681, João Lopes Ribeiro, que acumulaba funciones de corrector y traductor de los vizcaínos ${ }^{2}$.
Estos hechos evalúan el grado de intensidad y de madurez de los contactos que a nivel comercial se establecían con Galicia y que vemos traducidos, con escalas y ritmos diferentes, en núcleos urbanos como Caminha, Vila Nova de Cerveira y en las plazas militares de Valença y Monção, más próximas geográficamente. En el caso de los ayuntamientos de Vale do Lima, Ponte de Lima, Ponte da Barca y Arcos de Valdevez serán las vías terrestres, con mención especial para la gran vía romana terrestre que pasaba por Ponte de Lima, y el río Lima/Limia los que funcionaban como eje de comunicación de las conexiones con Galicia. Estos municipios eran también puntos de paso del Sur hacia el Norte, Braga-Monção y puntos de confluencia de carreteras que facilitaban la circulación de las personas y de las mercancías en ambos territorios fronterizos.

A esta cuestión de la movilidad transfronteriza tenemos que añadir otro elemento, el del trayecto de la peregrinación compostelana. Los ayuntamientos del Minho, el Lima y las vías terrestres y fluviales que les proporcionaban acceso habían sido, desde la época medieval, puntos de paso obligatorios de los peregrinos que se desplazaban hacia Santiago de Compostela. Estos trayectos, bien marcados en el itinerario del Camino Portugués, formaban parte de la denominada Tercera Vía, que atravesaba el río Minho por São Pedro da Torre, lugar de concentración de peregrinos que venían de Caminha, Arcos de Valdevez y Ponte de Lima ${ }^{3}$.

La capilaridad de las redes de comunicación de los municipios de frontera, del Minho-Lima con Galicia, aportó un aspecto más de relevante consideración: el estímulo a la construcción y establecimiento de un conjunto de infraestructuras para la acogida de peregrinos de paso, que proporcionaba una amplia red de monasterios, iglesias, capillas y ermitas, que se define de forma efectiva entre los siglos XV y XVI.

La configuración de estos territorios, marcada por la medida temporal del siglo XVI, que se asienta, sobre todo, en la expansión Portuguesa, dará un nuevo tono a las economías locales, principalmente en las comunidades atlánticas.

La diáspora lusa dejará profundas señales en estas comunidades, siendo una de las más evidentes, en el Norte atlántico portugués, el 
impulso constructivo encabezado por la corona, en una apremiante necesidad defensiva y de refuerzo de las estructuras administrativas y fiscales; por las estructuras eclesiásticas; por los movimientos laicos, con especial incidencia de las cofradías; por el poder municipal y por una aristocracia local con ansias de reafirmarse y obtener prestigio social que engrosaba las filas de las instituciones laicas de vocación asistencial, desempeñando cargos de prestigio como el de presidente de la Misericordia o de las cofradías. Al margen del anonimato de la base de la sociedad están también los mercaderes y banqueros, ricos y poderosos, que expiaban sus culpas y agravios mediante generosas donaciones a la Iglesia. Clientela y dinero son en los siglos XVI y XVII la firme razón de ser que respalda, asimismo, el desarrollo artístico observado de forma particularmente intensa en la región del Alto Minho, sobre todo en la franja atlántica. Esta condición generará dos fenómenos paralelos: el de la oferta y el de la demanda, que atraerá y, al mismo tiempo, solicitará mano de obra especializada. Este mercado transfronterizo se encuentra, de ese modo, abierto y se beneficiará de la especial coyuntura demográfica gallega, cuya población se duplica entre los siglos XVI y primera mitad del siglo XVIII. En 1591, la población gallega se calcula en torno a los 630.000 habitantes, mientras en 1752 este número alcanza el 1.300.000 habitantes ${ }^{4}$.

Este factor explicará, según Ramón Villares, un movimiento migratorio de gran amplitud que se refleja, por un lado, en la denominada emigración temporal dentro de la península, que tenía como destino las regiones de Castilla, Andalucía y Portugal, y la emigración definitiva, o de larga duración, que se concentraba sobre todo en los centros urbanos de Oporto, Lisboa y Madrid. En la segunda mitad del siglo XVIII 350.000 gallegos habrían abandonado su territorio para establecerse de forma más permanente en estos centros urbanos peninsulares ${ }^{5}$.

La movilidad de artistas y artesanos en el período de la época moderna se notó a ambos lados de la frontera, demostrando que también en esta dimensión se establecían y fijaban relaciones entre el Norte de Portugal y Galicia. El presente artículo trata sobre la presencia de maestros y oficiales canteros gallegos que ejer- cieron su actividad profesional en los municipios del valle del Lima, supliendo las necesidades derivadas del proceso de encargos artísticos.

Este fenómeno es más amplio que el típico paradigma de la emigración gallega. Su análisis debe, por lo tanto, centrarse en la existencia preestablecida secularmente de contactos continuos, regulares y persistentes entre las comunidades que se establecen en los territorios de frontera. Las fronteras tienen para estas comunidades tenues contornos y nunca se impusieron como barreras físicas de dimensión política, administrativa o militar.

Para los artistas y artesanos miñotos y gallegos, el espacio transfronterizo constituía el espacio de trabajo, de posibilidades profesionales más amplias, constatadas, principalmente, en los centros urbanos más dinámicos. El carácter de estas actividades es, por norma, limitado en el tiempo y, por ello, provisional, aunque suficientemente expresivo en cantidad y calidad.

No podremos hablar propiamente de comunidades organizadas de artistas, sino de profesionales de su oficio que se presentaban aisladamente o con sus pequeños equipos de obreros. Se constata, asimismo, el fenómeno de contingentes de obreros que, de forma más espontánea, se hacían reclutar para las obras que se ejecutaban en los núcleos urbanos próximos. Como contrapunto a este movimiento, se identifica otro, más disperso y puntual, menos documentado todavía, y que se materializa en la identificación y elección deliberada de un determinado profesional por parte del contratante. Impera por lo tanto, en esta dinámica, la voluntad deliberada de quien ordena ejecutar y paga la obra.

Los centros de formación artística, las células de desarrollo de talleres de artistas y artesanos de amplia y cualificada experiencia se encuentran polarizados en las diócesis gallegas de Tui, Ourense y Santiago, marcadas por un auge artístico inigualable. Estos talleres abastecían la exigente, variada y prolífera demanda constructiva de los poderosos señores eclesiásticos gallegos. Como paradigma de este fenómeno, la Iglesia compostelana y sus arzobispos «mantiveram com firmeza a sua condição não só de senhores espirituais, que ninguém negava, mas também materiais» ${ }^{6}$. 
La primacía social que esta nobleza eclesiástica poseía justificará, dentro de una lógica de política de prestigio, la amplia e inigualable diversificación de actividades que se notará en todas las artes. Los señores eclesiásticos gallegos son también grandes mecenas.

En Santiago de Compostela y bajo el escudo del gran mecenas de la catedral, el Arzobispo Fray Antonio Monroy, trabajaron artistas de la importancia de Andrade, Fray Gabriel de Casas, Fernando Casas, Miguel de Romay y García de Bouzas, que imprimen al barroco compostelano una calidad única comparable a los mejores ejemplos europeos ${ }^{7}$.

La gigantesca obra compostelana es mucho más que un laboratorio de competencias desarrolladas por los artistas que en ella trabajan; marca, también, una cima de intercambio artístico entre el Norte de Portugal y Galicia, puntualmente documentado mediante un extenso repertorio de nombres de ambos lados de la frontera.

En el caso del Norte del país, se pasó a percibir el fenómeno de estas relaciones artísticas con las provincias gallegas de una forma más clarividente. Los contactos entre estos territorios vecinos, por lo que al intercambio artístico respecta, vienen de antaño y se manifiestan en la arquitectura, en la escultura, en la talla y en la pintura. Estudios, parciales, eso sí, apuntan hacia una determinada unidad estética que se presenta de forma más evidente en la franja litoral de los dos territorios, aunque carece de confirmación.

Al analizarse el fenómeno de la presencia de artistas gallegos en territorio del Alto Minho, la bibliografía más difundida sacó a la luz algunos de los más relevantes artistas. En Caminha, en la construcción de la iglesia mayor de esa villa (finales del siglo XV - primera mitad del siglo XVI), se impusieron los nombres de los gallegos y vizcaínos como João de Castilho, Pero Galego, Tomé de Tolosa y Francisco Fial ${ }^{8}$.

Otros nombres de artistas y artesanos gallegos, con menos renombre por ser desconocidos, van cubriendo el marco de las referencias artísticas, dejando sus marcas en la arquitectura, en la producción de retablos y en las artes de la madera en general.
Observando el panorama general de las obras ejecutadas por artistas y artesanos gallegos en la región del Lima se ha podido constatar, mediante la investigación realizada, que gran parte de la mano de obra gallega era absorbida en las obras de carácter arquitectónico y específicamente de encomienda religiosa, si bien en casos puntuales los maestros canteros gallegos son contratados para ejecutar obras de arquitectura civil. Sin embargo, la investigación que queda por hacer suscita muchas cuestiones dirigidas a descubrir de forma más precisa la expresión y dimensión de las obras de estos artistas.

Surge, aún, otra cuestión relacionada con el análisis de las fuentes primarias: si, por un lado, es posible identificar al artista, su oficio y su categoría, existen otros casos en los que apenas deja su impronta, sin que existan elementos de identificación, ni del artista o artesano, ni del oficio y categoría; la documentación los presenta con actividad no diferenciada.

\section{Obras de arquitectura religiosa}

\section{Artistas y artesanos gallegos no identificados}

Tomando como ejemplo el núcleo de Viana do Castelo, se detecta, en la investigación realizada en los archivos de las cofradías de la Iglesia Mayor, contingentes de obreros gallegos, no identificados. Esto sucede en 1588, en las obras de la construcción de la sacristía de la cofradía del Santísimo Sacramento: del equipo de obreros forma parte un oficial gallego, no identificado en la documentación?.

Y en 1746, también en la Iglesia Mayor de Viana do Castelo, en las obras de la torre que la cofradía del Espíritu Santo construía, y que estaba adosada a su consistorio y sacristía, proyectada por el ingeniero militar Manuel Pinto Vilalobos y ejecutada por el maestro albañil Bento Lourenço, encontramos, en la conclusión de la aguja de la torre, a un aprendiz gallego, cuyo nombre la documentación omite (Fig. 1) ${ }^{10}$.

En Ponte da Barca, las obras que la Misericordia emprende en 1732, específicamente sacristía, claustro y consistorio, son ejecutadas por oficiales de cantería gallegos, cuyo nombre 
y número se ignoran ${ }^{11}$ una vez más. Esta misma institución declara, en los gastos de la obra de la capilla mayor que está ejecutando en 1754, el pago de honorarios a un maestro cantero natural del reino de Galicia (Fig. 2) ${ }^{12}$.

Pero, si esta realidad presenta diluida la intervención de estos oficiales, indicando poco más que la fecha, el patrón y el emplazamiento de la obra, otros datos permiten establecer con seguridad el dominio que los maestros canteros gallegos poseían del modus operandi de los elaborados procesos de licitación de obras y del mercado potencial para el desempeño de su oficio.

\section{Maestros canteros gallegos. \\ Dinámicas constructivas en Ponte da Barca y Arcos de Valdevez}

Como se verá, las cofradías más prestigiosas y las Misericordias destacan entre el abanico de patronos que sufragaban obras en los edificios que se hallaban bajo su tutela directa.

Las intervenciones de carácter arquitectónico que recurren a maestros canteros gallegos, más frecuentes en estos municipios del valle del Lima, son esencialmente construcciones de plantas, y, partiendo de este presupuesto, toman la delantera las iglesias parroquiales, la reformulación de fachadas de templos y la construcción o reconstrucción de unidades físicas, como capillas mayores, sacristías o campanarios.

Por norma, a dichas obras se les daba publicidad y eran reguladas mediante un complejo marco de exigencias legales que las partes contratantes debían respetar íntegramente; además, el maestro contratado debía cumplir obligatoriamente los apuntes y el plano de la obra que, a su conclusión, sería evaluada por peritos del mismo oficio. En estos casos en concreto, tenemos documentados maestros de cantería oriundos de Galicia que responden a las licitaciones de obras, presentando sus ofertas junto a otros maestros del área regional de influencia o hasta de otras localidades de la comarca de Entre Douro y Minho.

En concreto, para las obras de ampliación de la capilla mayor de la iglesia del Espíritu Santo, en Arcos de Valdevez, los maestros canteros gallegos Dionisio Salgado y José Pires presentan en 1746 sus ofertas junto con otros maestros de cantería de Paredes de Coura, Arcos de Valdevez y Caminha (Fig. 3) ${ }^{13}$.

Al maestro cantero Dionisio Salgado esta cofradía le adjudica, en 1748-1749, la obra del muro de la plaza donde se situaba la Iglesia del Espíritu Santo ${ }^{14}$.

Esta realidad demuestra que, de hecho, el territorio de la cuenca del Lima se presentaba como un mercado de trabajo efectivo para los maestros de cantería gallegos que se lanzan a la licitación de obras de gran escala y envergadura, como ejemplificaremos a continuación.

\section{MUNICIPIO DE PONTE DA BARCA Iglesia de la parroquia de Britelo}

La escritura de obra de la iglesia parroquial de la parroquia de Britelo, con fecha de 2 de diciembre de 1726, fue firmada entre el presidente de la cofradía del Subsino y los maestros canteros Francisco y Pedro Gonçalves, naturales de Pontevedra (Galicia). Este templo, que se construyó por completo, tendría un largo de 66 palmos, un ancho de 26 y una altura de 25 . Llevaría un arco crucero y tres ventanucos, dos en cada uno de los alzados y uno en el frontispicio. El contrato incluía dos puertas, una principal y otra lateral, y un campanario. Según este documento, los maestros canteros seguirían el plano y las anotaciones, teniendo como modelo la iglesia de Entre Ambos-os-Rios. Mediante este contrato, los maestros gallegos estaban, incluso, obligados a fabricar el púlpito, canecillos para el coro, hornacinas para los santos óleos y vinajeras y pilas de agua bendita; además, tenían que ocuparse de partir la piedra para la obra. El importe de este acuerdo ascendió a 97.000 reales y la obra debía estar concluida a principios de agosto de 1727, fase en la que pasarían revista peritos del mismo oficio.

La obra de cantería de la capilla mayor y sacristía de esta iglesia fue ejecutada, igualmente, por maestros canteros gallegos, João Rodrigues y Bento Rodrigues, también naturales de Pontevedra. La escritura se firma el 21 de marzo de 1730.

La capilla mayor, tal y como determinaba el plano, debía tener un largo de 28 palmos y un ancho de 20. En altura debía corresponderse al 
cuerpo de la iglesia. En el alzado este se colocaría un ventanuco. Por la obra se acordó un precio de 70.000 reales, pagados en tres fases, la primera tras cortar y transportar la piedra a la obra, la segunda a mitad de la construcción y la tercera al finalizar la obra, que debía concluir en agosto, el día de San Lorenzo de 1731, sometiéndose posteriormente a inspección a cargo de maestros del oficio, que evaluaban el respeto al plano y las anotaciones ${ }^{15}$.

Dentro del amplio conjunto de obras que la Misericordia de Ponte da Barca lleva a cabo en su iglesia en la segunda mitad del siglo XIX, se realizaron una serie de intervenciones en el espacio circundante. El programa de acondicionamiento exterior contemplaba la construcción de la Capilla del Señor de los Pasos, adjudicada en 1832 a Bento Pires, maestro cantero gallego. Esta capilla, que formaría parte de un conjunto de pequeños retablos pétreos de la vía sacra, estaba localizada frente a la sacristía de la Misericordia ${ }^{16}$.

\section{Iglesia de la parroquia de Vila Chã}

Los oficiales de la cofradía del Subsino, de la parroquia de Vila Chã, adjudicaron en 1812, al maestro cantero Carlos António de Deus, «natural del reino de Galicia», la obra de su iglesia, por un importe de 468.000 reales. Esta obra consistía en la demolición de la fachada del antiguo templo y en la construcción de una nueva, que incluía una puerta coronada con un ventanuco y rematada por una cruz y cuatro pirámides idénticas a la de la capilla mayor. Los vanos de los alzados laterales (puertas y ventanucos) también serían retocados, a fin de ajustar las medidas de altura y anchura.

La demolición de la fachada, la eliminación de escombros, el transporte de los materiales, dietas, cal, arena, rejas, vidrieras y redes de los tres ventanucos serían a costa del maestro cantero. La ejecución de esta obra debía realizarse garantizando que no se alterase la capilla del Santísimo Sacramento ${ }^{17}$.

\section{MUNICIPIO DE ARCOS DE VALDEVEZ} Iglesia de la parroquia de São Pedro de Vale

Para la iglesia de Nossa Senhora do Vale de la parroquia de Vale, Francisco de Araújo y André
Cerqueira, "Hombres Buenos", contrataron la obra del patio que está frente a la fachada principal de la iglesia. Esta escritura de contrato, con fecha de 21 de noviembre de 1729, nos indica que el contrato se firmó con los maestros canteros Eugénio da Torre e Inácio Baceiro, naturales de Pontevedra (Galicia), asistentes en la parroquia de Paço, en Arcos de Valdevez ${ }^{18}$.

\section{Iglesia mayor de São Salvador de Arcos de Valdevez}

Al servicio de la cofradía de Santo António de la iglesia mayor de Arcos de Valdevez nos encontramos al maestro cantero natural de Galicia Alberto de Vila Verde, al que, en 1741, se le asignó proceder a la colocación de las rejas y reparación del enlosado de la capilla de Santo António. Este maestro cantero gallego será el autor de la obra de cantería de la capilla mayor de la iglesia de la parroquia de Padreiro, del mismo ayuntamiento de Arcos de Valdevez, adjudicada por 300.000 reales en 1750 . En esta obra colaboró con su coterráneo, el también maestro cantero Miguel de Marcán, natural de Pontevedra (Fig. 4) $)^{19}$.

\section{Iglesia de la parroquia de Couto}

El contrato de adjudicación de la obra de la iglesia de la parroquia de Couto se le asignó en 1747 al maestro carpintero de Ponte da Barca Tomás de Araújo, por un precio de 375.000 reales. Tomás de Araújo subcontratará, para la obra de albañilería, a los maestros canteros gallegos Dionisio Salgado y Jozeph Hereres. La obra debería entregarse a finales de diciembre de 1747, para su debida evaluación ${ }^{20}$.

\section{Iglesia parroquial de São Paio}

En la vecina parroquia de São Paio de Arcos de Valdevez, situada en el otro lado del río, se encuentra la iglesia parroquial con la misma advocación. Esta iglesia parroquial se demuele a finales del siglo XVIII ante la amenaza de ruina, y se inicia la construcción de un nuevo templo a finales de ese siglo e inicios del siguiente: «No lugar da Egreja Velha esteve o primeiro templo, que foi demolido há cerca de um século por ameaçar ruina. O actual foi começado em 1781, e terminou-se em $1831(\ldots)\rangle^{21}$. 


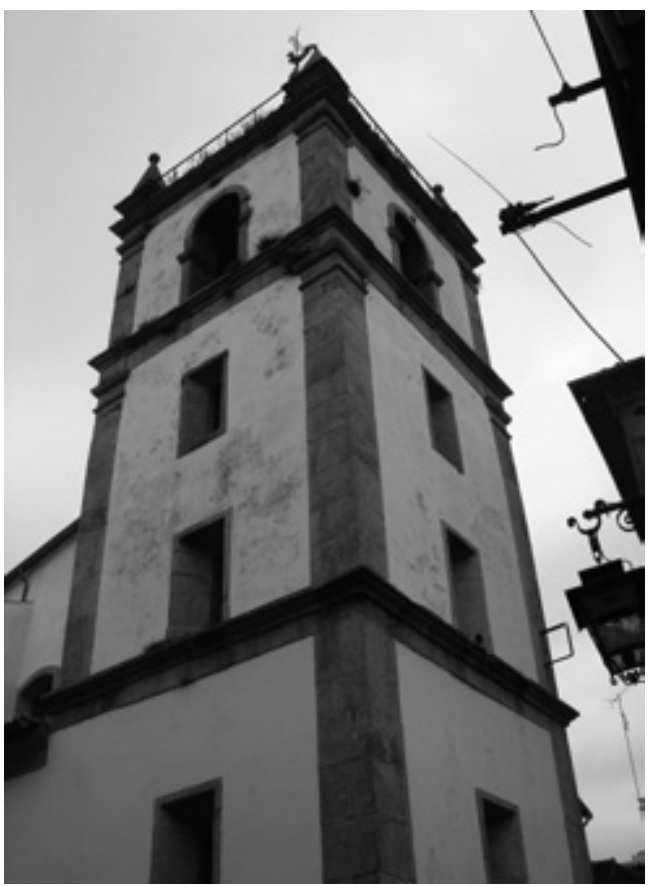

Fig. 1. Torre de la cofradía del Espíritu Santo. Iglesia Mayor de Viana do Castelo (1746). Foto de la autora.

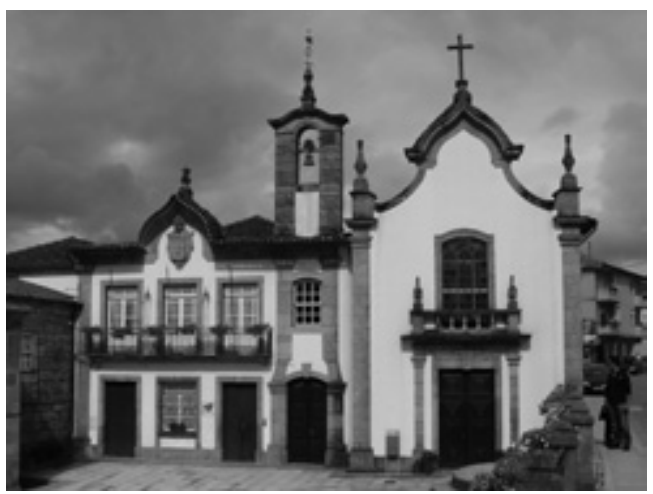

Fig. 2. Misericordia de Ponte da Barca. Foto de la autora.

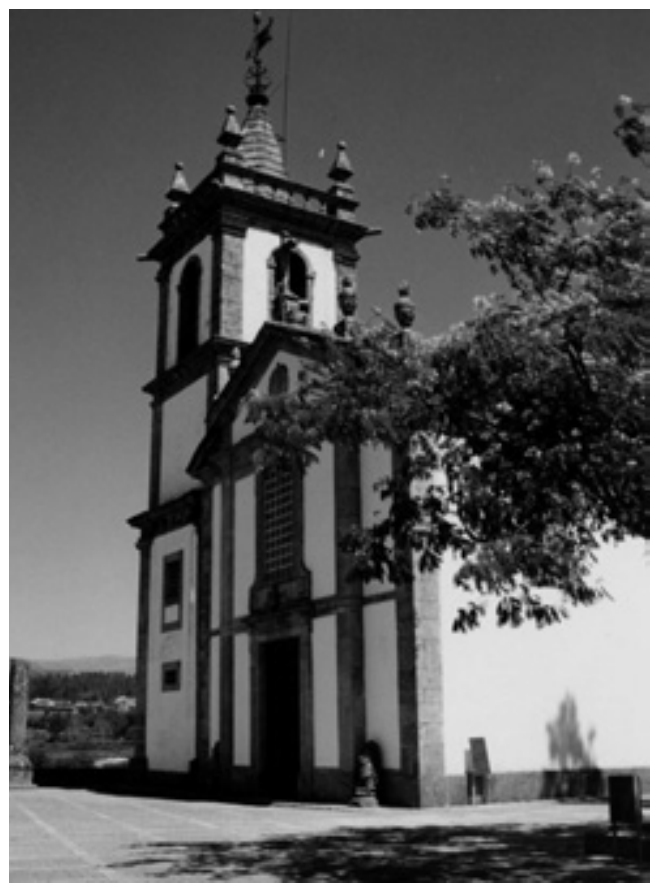

Fig. 3. Iglesia del Espíritu Santo de Arcos de Valdevez. Foto de la autora.

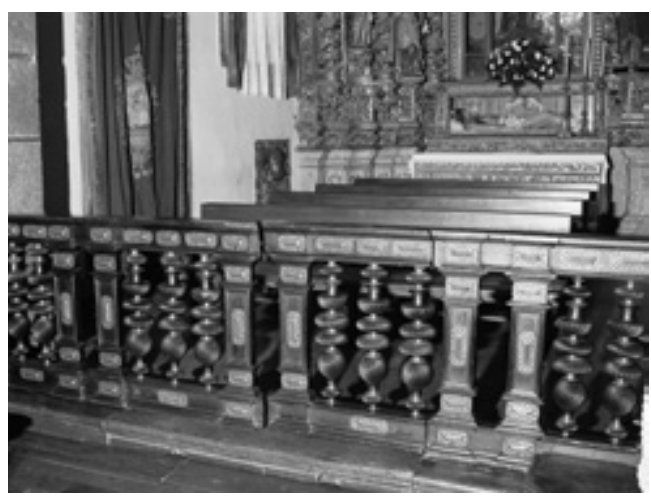

Fig. 4. Gradas de la capilla de San Antonio. Iglesia Mayor de Arcos de Valdevez. Foto de la autora. 
De acuerdo con la escritura de traspaso, firmada en 1810, obtuvimos la información de que el maestro cantero gallego Carlos António de Deus se hizo con la obra de la escalinata de la iglesia por un importe de 444.000 reales, pretendiendo traspasarla, con todas las cláusulas de obligación, al maestro cantero João Alves, de la parroquia de Gondoriz, Arcos de Valdevez, quien se comprometió a cumplir las estipulaciones contractuales establecidas en el primer acuerdo ${ }^{22}$.

\section{Iglesia Parroquial de Távora (Santa Maria)}

Manuel António Machado, mencionado en la escritura de contrato como señor de la parroquia de Távora (Santa Maria), contrata en 1810, al maestro cantero natural de Galicia Ignácio Iglezias, para ejecutar la obra de reforma de la iglesia parroquial ${ }^{23}$.

\section{Iglesia parroquial de Aboim}

En la iglesia parroquial de la parroquia de Aboim, cuya obra de cantería procede del 1804, se construyó una torre en 1825, por encargo de los "hombres buenos" de esa parroquia y adjudicada a Joze Magdaleno, quien, como el documento menciona, era natural de Galicia y residía en $\operatorname{Arcos}$ de Valdevez ${ }^{24}$.

\section{Iglesia de la Misericordia}

Los maestros canteros gallegos Joze Magdaleno y Carlos de Deus, activos en los ayuntamientos de Ponte da Barca y Arcos de Valdevez en la primera mitad del siglo XIX, formarán equipo en 1826 para las obras de la iglesia de la Misericordia de Arcos de Valdevez, específicamente, frontispicio y atrio de la iglesia (Fig. 5) ${ }^{25}$.

\section{Conclusión}

De acuerdo con la documentación recopilada, extraemos un conjunto de nombres de maestros canteros oriundos de Galicia y activos en la cuenca del Lima entre 1726 y 1832 (Tab. 1).

La presencia de maestros canteros oriundos de Galicia en un periodo tan amplio nos obliga a reflexionar acerca de otra dimensión de la problemática artística, la de las influencias estilísticas que dichos maestros canteros habrán imprimido a estos ejemplos arquitectónicos, suscitando algunas cuestiones de fondo: ¿Qué

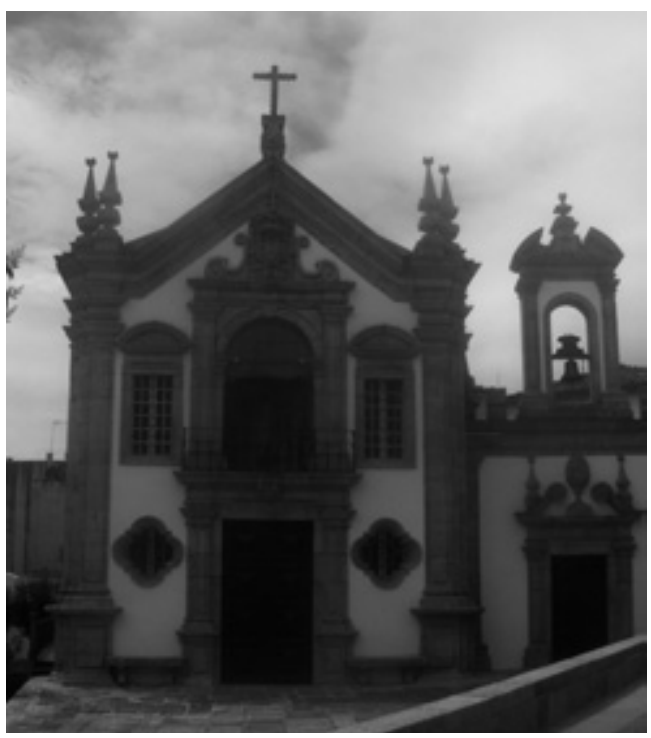

Fig. 5. Iglesia de la Misericordia de Arcos de Valdevez. Foto de la autora.

rasgo diferenciador se revela en estas muestras de labra gallega? ¿Se podrá establecer un paralelismo entre la autoría de las obras y el carácter innovador, de difícil percepción, que se puede observar en cuanto a lenguaje ornamental? ¿Estarían condicionados estos maestros canteros por el estricto cumplimiento de las normas contractuales o bien es una característica o indicación del presupuesto del mecenas? ¿Habrán plasmado esos artistas, pese a algunos condicionantes, su firma personal, alterando el resultado final de la obra? Si, en algunos casos, parece obvia la materialización de esa influencia, en otros dichas cuestiones no se verifican.

Las respuestas a todas estas cuestiones dependen de una ardua y perseverante recopilación formal de base territorial, que posibilite comparaciones rigurosas y el cruce de fuentes, a fin de obtener un conocimiento profundo de la actividad de estos y de otros maestros gallegos, de sus obras y del circuito de patronos. Sólo de esta forma podremos abrir pistas sólidas para el estudio y análisis de la muchas veces defendida unidad estética en la franja litoral de los dos territorios. 


\begin{tabular}{|c|c|c|c|}
\hline FECHA & ARTISTA & LOCALIDAD & FUENTE \\
\hline $\begin{array}{l}\text { 1726, } 22 \text { de } \\
\text { diciembre }\end{array}$ & $\begin{array}{l}\text { Francisco } \\
\text { Gonçalves } \\
\text { (maestro) }\end{array}$ & $\begin{array}{l}\text { Parroquia de Sta. } \\
\text { María de } \\
\text { Mourente (Pon- } \\
\text { tevedra, Galicia) }\end{array}$ & $\begin{array}{l}\text { A.D.V.C., Fondo Notarial de Ponte da Barca, Libro de } \\
\text { Notas, Notario: MUHIA, Francisco Cerqueira, } 3^{\circ} \text { Oficio, } \\
\text { Hj. 200Vto. }-202\end{array}$ \\
\hline $\begin{array}{l}\text { 1726, } 22 \text { de } \\
\text { diciembre }\end{array}$ & $\begin{array}{l}\text { Pedro } \\
\text { Gonçalves } \\
\text { (maestro) }\end{array}$ & $\begin{array}{l}\text { Parroquia de Sta. } \\
\text { María de } \\
\text { Mourente (Pon- } \\
\text { tevedra, Galicia) }\end{array}$ & $\begin{array}{l}\text { A.D.V.C., Fondo Notarial de Ponte da Barca, Libro de } \\
\text { Notas, Notario: MUHIA, Francisco Cerqueira, } 3^{\circ} \text { Oficio, } \\
\text { Hj. 200Vto. }-202\end{array}$ \\
\hline $\begin{array}{l}1727,31 \mathrm{de} \\
\text { agosto }\end{array}$ & $\begin{array}{l}\text { Inácio } \\
\text { Baceiro } \\
\text { (maestro) }\end{array}$ & $\begin{array}{l}\text { Parroquia de S. } \\
\text { André de Gebe } \\
\text { (Pontevedra, } \\
\text { Galicia) }\end{array}$ & $\begin{array}{l}\text { A.D.V.C., Fondo Notarial de Arcos de Valdevez, Libro } \\
\text { de Notas, Notario: CUNHA, João Alves da, } 2^{\circ} \text { Oficio, } \\
\text { Hj. } 353 \text { to. }-355 \text { to. }\end{array}$ \\
\hline $\begin{array}{l}\text { 1729, } 21 \text { de } \\
\text { noviembre }\end{array}$ & $\begin{array}{l}\text { Eugénio } \\
\text { da Torre } \\
\text { (maestro) }\end{array}$ & $\begin{array}{l}\text { Parroquia de S. } \\
\text { André de Gebe } \\
\text { (Pontevedra, } \\
\text { Galicia) }\end{array}$ & $\begin{array}{l}\text { A.D.V.C., Fondo Notarial de Arcos de Valdevez, Libro } \\
\text { de Notas, Notario: CUNHA, João Alves da, } 2^{\circ} \text { Oficio } \\
\text { Hj. } 353 \text { to. }-355 \text { to. }\end{array}$ \\
\hline $\begin{array}{l}\text { 1730, } 21 \mathrm{de} \\
\text { marzo }\end{array}$ & $\begin{array}{l}\text { Bento } \\
\text { Rodrigues } \\
\text { (maestro) }\end{array}$ & $\begin{array}{l}\text { Parroquia de S. } \\
\text { Salvador de Lérez } \\
\text { (Pontevedra, } \\
\text { Galicia) }\end{array}$ & $\begin{array}{l}\text { A.D.V.C., Fondo Notarial de Ponte da Barca, Libro de } \\
\text { Notas, Notario: LEMOS, João de, } 1^{\circ} \text { Oficio Hj. } 91- \\
92 \text { Vto. }\end{array}$ \\
\hline $\begin{array}{l}\text { 1730, } 21 \text { de } \\
\text { marzo }\end{array}$ & $\begin{array}{l}\text { João } \\
\text { Rodrigues } \\
\text { (maestro) }\end{array}$ & $\begin{array}{l}\text { Parroquia de S. } \\
\text { Salvador de Lérez } \\
\text { (Pontevedra, } \\
\text { Galicia) }\end{array}$ & $\begin{array}{l}\text { Archivo de la Iglesia Mayor de Arcos de Valdevez, } \\
\text { Libro Haber y Debe, } 1682-1747 \text {, cofradía de Santo } \\
\text { António, Hj. 132Vto. - } 134 \text { Vto. }\end{array}$ \\
\hline $1744-1745$ & $\begin{array}{l}\text { Alberto de } \\
\text { Vila Verde } \\
\text { (maestro) }\end{array}$ & Galicia & $\begin{array}{l}\text { Archivo de la Iglesia Mayor de Arcos de Valdevez, } \\
\text { Iglesia del Espíritu Santo, Documentos sueltos, } \\
\text { cofradía del Espíritu Santo, [s. Hj.] }\end{array}$ \\
\hline $\begin{array}{l}\text { 1746, } 15 \text { de } \\
\text { diciembre }\end{array}$ & $\begin{array}{l}\text { Dionisio } \\
\text { Salgado } \\
\text { (maestro) }\end{array}$ & Galicia & $\begin{array}{l}\text { Archivo de la Iglesia Mayor de Arcos de Valdevez, } \\
\text { Iglesia del Espíritu Santo, Documentos sueltos, } \\
\text { cofradía del Espíritu Santo, [s. Hj.] }\end{array}$ \\
\hline $\begin{array}{l}\text { 1746, } 15 \text { de } \\
\text { diciembre }\end{array}$ & $\begin{array}{l}\text { José Pires } \\
\text { (maestro) }\end{array}$ & Galicia & $\begin{array}{l}\text { A.D.V.C., Fondo Notarial de Arcos de Valdevez, Libro } \\
\text { de Notas, Notario: FARIA, João Durães e COELHO, } \\
\text { Joaquim Inácio, } 2^{\circ} \text { Oficio Hj. } 81 \text { - } 82 \text { Vto. }\end{array}$ \\
\hline $\begin{array}{l}1761,3 \text { de } \\
\text { octubre }\end{array}$ & $\begin{array}{l}\text { Angelo } \\
\text { Guiteiro } \\
\text { (maestro) }\end{array}$ & Galicia & $\begin{array}{l}\text { A.D.V.C., Fondo Notarial de Arcos de Valdevez, Libro } \\
\text { de Notas, Notario: FARIA, João Durães e COELHO, } \\
\text { Joaquim Inácio, } 2^{\circ} \text { Oficio Hj. } 81 \text { - } 82 \text { Vto. }\end{array}$ \\
\hline $\begin{array}{l}1761,3 \text { de } \\
\text { octubre }\end{array}$ & $\begin{array}{l}\text { Francisco } \\
\text { Bento Loureiro } \\
\text { (maestro) }\end{array}$ & Galicia & $\begin{array}{l}\text { A.D.V.C., Fondo Notarial de Arcos de Valdevez, Libro } \\
\text { de Notas, Notario: RODRIGUES, António José, } 5^{\circ} \\
\text { Oficio Hj. } 11 \text { Vto. }-13\end{array}$ \\
\hline
\end{tabular}

Tabla 1. Maestros canteros gallegos activos en Ponte da Barca y Arcos de Valdevez. 


\begin{tabular}{|c|c|c|c|}
\hline FECHA & ARTISTA & LOCALIDAD & FUENTE \\
\hline $\begin{array}{l}1810,7 \text { de } \\
\text { marzo }\end{array}$ & $\begin{array}{l}\text { Ignácio } \\
\text { Iglezias } \\
\text { (maestro) }\end{array}$ & $\begin{array}{l}\text { Pontevedra, } \\
\text { Galicia }\end{array}$ & $\begin{array}{l}\text { A.D.V.C., Fondo Notarial de Arcos de Valdevez, Libro } \\
\text { de Notas, Notario: LIMA, Caetano José da Silva, } 6^{\circ} \\
\text { Oficio Hj. } 104 \text { Vto. - } 106\end{array}$ \\
\hline $\begin{array}{l}1812,16 \text { de } \\
\text { marzo }\end{array}$ & $\begin{array}{l}\text { José } \\
\text { Madaleno } \\
\text { (maestro) }\end{array}$ & Galicia & $\begin{array}{l}\text { A.D.V.C., Fondo Notarial de Ponte da Barca, Libro de } \\
\text { Notas, Notario: MENESES, João Gonçalves, } 4^{\circ} \text { Oficio } \\
\text { Hj. } 58-59\end{array}$ \\
\hline $\begin{array}{l}\text { 1829, } 20 \text { de } \\
\text { enero }\end{array}$ & $\begin{array}{l}\text { Julião Torre } \\
\text { (maestro) }\end{array}$ & $\begin{array}{l}\text { Parroquia de Sta. } \\
\text { María de } \\
\text { Mourente (Pon- } \\
\text { tevedra, Galicia) }\end{array}$ & $\begin{array}{l}\text { A.D.V.C., Fundo Notarial de Ponte da Barca, Libro de } \\
\text { Notas, Notario: PALHÃO, João António Dias, COSTA, } \\
\text { José Gomes da e MAGALHÃES, João José Soares da } \\
\text { Costa, } 3^{\circ} \text { Oficio Hj. } 77-78\end{array}$ \\
\hline $\begin{array}{l}1829,20 \text { de } \\
\text { julio }\end{array}$ & $\begin{array}{l}\text { Carlos } \\
\text { António de } \\
\text { Deus }\end{array}$ & Galicia & $\begin{array}{l}\text { Archivo de la Misericordia de Ponte da Barca, Libro de } \\
\text { las Determinaciones de la Santa Casa de la Misericor- } \\
\text { dia de Ponte da Barca, 1815, Hj. 26-26v }\end{array}$ \\
\hline $\begin{array}{l}1832,17 \text { de } \\
\text { septiembre }\end{array}$ & $\begin{array}{l}\text { Bento Pires } \\
\text { (maestro) }\end{array}$ & Galicia & $\begin{array}{l}\text { Archivo de la Misericordia de Ponte da Barca, Libro de } \\
\text { las Determinaciones de la Santa Casa de la Misericor- } \\
\text { dia de Ponte da Barca, 1815, Hj. 26-26Vto. }\end{array}$ \\
\hline
\end{tabular}

Tabla 1 (cont.). Maestros canteros gallegos activos en Ponte da Barca y Arcos de Valdevez.

\section{BIBLIOGRAFIA}

ALVES, Jorge Fernandes, 2002 «Imigração de galegos no Norte de Portugal (1500-1900). Algumas notas». In ROEL, Antonio Eiras; LOPO, Domingo Gonzalez (coord.) - Movilidade e migracións internas na Europa Latina. Unesco. Santiago de Compostela: Universidad (Cátedra Unesco), pág. 117-126.

CARDONA, Paula Cristina Machado, 2004 - A Actividade Mecenática das Confrarias nas Matrizes do Vale do Lima nos Séculos XVII a XIX, 4 Vol. Oporto: Facultad de Letras de la
Universidad de Oporto. [Tesis doctoral multicopiada], Vol. I.

GOY, Ana, A Influencia dos modelos de João Lopes o Velho en Terras Galegas nos albores do Barroco. In Cadernos vianenses, Tomo 19, Viana do Castelo, Ayuntamiento, pág. 137-139.

GONZÁLES-PAZ, Carlos Andrés, 2009 - «La Orden de San Juan de Jerusalém Y Las Peregrinaciones En La Galicia Medieval (Siglos XII-XIII)». In Revista População e Sociedade, $n .^{\circ} 17$. Oporto: Cepese, pág. 12.

PEREIRA, Esteves, RODRIGUES, Guilherme, 1904 - Portugal Dicciona- rio Historico, Chorográfico, Heraldico, Biographico, Bibliographico, Numismatico e Artistico. Lisboa: ed. João Ramos Torres, pág. 683.

VILA JATO, Maria Dolores, 1991 Promotores, Clientes y Talleres en la Galicia Barroca, in Actas del I Congreso Internacional del Barroco, Oporto, ed. Rectorado de la Universidad de Oporto - Gobierno Civil de Oporto, ॥ Vol. pág. 36.

VILLARES, Ramón, 1991 - História da Galiza. Lisboa: Livros Horizonte, pág. 85. 
NOTAS

${ }^{1}$ Archivo Histórico Municipal de Viana do Castelo, «Livro dos Acordaons da Câmara 1717-1720», Hj. 128-128Vto.; 130-130Vto.; 135Vto.136.

2 CARdONA, Paula Cristina Machado, 2004, A Actividade Mecenática das Confrarias nas Matrizes do Vale do Lima nos Séculos XVII a XIX, 4 Vol. Oporto: Facultad de Letras de la Universidad de Oporto. [Tesis doctoral multicopiada], Vol. I, pág. 53.

${ }^{3}$ GONZÁLES-PAZ, Carlos Andrés, 2009 -La Orden de San Juan de Jerusalén y las Peregrinaciones en la Galicia Medieval (Siglos XII-XIII). In Revista População e Sociedade, n. ${ }^{\circ 17}$. Oporto: Cepese, pág. 12.

${ }^{4}$ VILLARES, Ramón, 1991 - História da Galiza. Lisboa: Livros Horizonte, pág. 85.
${ }^{5}$ Ídem, ibídem, pág. 86.

${ }^{6}$ Ídem, ibídem, pág. 72.

7 VILA JATO, Maria Dolores, 1991, Promotores, Clientes y Talleres en la Galicia Barroca, in Actas del I Congreso Internacional del Barroco, Oporto, ed. Rectorado de la Universidad de Oporto - Gobierno Civil de Oporto, II Vol. pág. 36.

8 GOY, Ana, A Influencia dos modelos de João Lopes o Velho en Terras Galegas nos albores do Barroco. In Cadernos vianenses, Tomo 19, Viana do Castelo, Ayuntamiento, pág. 137-139.

9 CARDONA, Paula Cristina Machado, Ob. cit. pág. 167.

10 Ídem, ibídem, pág. 132.

${ }^{11}$ Ídem, ibídem, pág. 692.

12 Ídem, ibídem, pág. 694.

13 Ídem, ibídem, pág. 769. Los maestros canteros gallegos Dionisio
Salgado y José Pires presentaron, para la ejecución de la obra, respectivamente, el precio de $440.000 \mathrm{y}$ 430.000 reales.

14 ídem, ibídem, pág. 774.

15 Ídem, ibídem, pág. 735-736.

16 Ídem, ibídem, pág. 703.

17 Ídem, ibídem, pág. 729.

18 ídem, ibídem, pág. 810.

19 Ídem, ibídem, pág. 810.

20 ídem, ibídem, pág. 813.

${ }^{21}$ PEREIRA, Esteves, RODRIGUES, Guilherme, 1904 - Portugal Diccionario Historico, Chorográfico, Heraldico, Biographico, Bibliographico, Numismatico e Artistico. Lisboa: ed., João Ramos Torres, pág. 683.

22 CARDONA, Paula Cristina Machado, Ob. cit., pág. 792.

${ }^{23}$ Ídem, ibídem, pág. 807.

24 Ídem, ibídem, pág. 821.

${ }^{25}$ Ídem, ibídem, pág. 529. 


\title{
TEXTO ORIXINAL
}

\author{
Relações artisticas transfronteiriças. \\ A actividade dos pedreiros galegos na bacia do Lima na Época Moderna
}

\author{
Paula Cristina Machado Cardona \\ Centro de Estudo da Economia, População \\ e Sociedade da Universidade do Porto
}

São vários os factores que subjazem, como permanência e continuidade, de um território separado por duas nações. Dentre esses factores, o geográfico impõe-se como o mais marcante, mas a esta características deve ser somada a matriz linguística, cultural e quiçá, num determinado tempo, a artística. Estamos a falar do noroeste peninsular e da sua particularidade identitária no contexto dos dois países da Ibéria, Portugal e Espanha.

Estes particularismos que aproximam o território Minho Lima da Galiza e vice-versa entroncam, num núcleo comum marcado por processos de clivagem e convergências que a história explica e que a vontade dos homens conferiu atributos distintivos que permanecem nestas duas comunidades.

A matriz comum, constitui um tema fechado, a construção das fronteiras políticas, eclesiásticas e administrativas, não coartaram as trocas económicas de matriz comercial, os movimentos migratórios de base social e os intercâmbios culturais. A região da Galiza e Portugal, em particular o Norte, apresentaram-se sempre como contiguidade geográfica e território económico comum, que partilham a mesma origem histórica, a mesma base cultural e a mesma estrutura lexical.

Os territórios atlânticos do Norte de Portugal sempre mantiveram, mesmo após a definição das fronteiras e as fragmentações políticas e religiosas, relações mercantis com a vizinha Galiza, como se testemunha no caso particular de Viana do Castelo, mais desenvolvida economicamente, que os restantes concelhos portugueses dos vales do Minho e Lima, que manterá de forma estruturada, desde a Idade-Média ligações comerciais com o território galego. Estes contactos eram essencialmente marítimos, as frotas vianenses navegavam regularmente pela costa da Galiza e Biscaia e do porto de mar escoavam-se todo o género de produtos para a Galiza. Estas relações, de base económica, são bem patentes nos séculos subsequentes sustentadas por mecanismos de carácter administrativo que demonstravam, a seu tempo, a importância dos contactos que ao mais diverso nível se estabeleciam com as províncias galegas e com o reino da Biscaia. Referimo-nos aos instrumentos de carácter administrativo, documentados no arquivo Municipal de Viana do Castelo, que dizem respeito ao governo e à gestão local, que se relacionam por um lado, com medidas regulamentares de protecção comercial de que é exemplo, em 1719, a implementação de restrições dirigidas às frotas galegas e biscainhas proibindo o escoamento de prata e ouro por rarearem em Viana do Castelo' e, por outro lado, a existência de um corpo de oficiais municipais, com função de tradutores que em alguns casos acumulavam com funções consulares, denominado "partido das línguas", que na sua essência eram cargos de nomeação municipal, exercidos por um período de três anos, ocupados por nacionais ou por estrangeiros, residentes em Viana, que podiam ser providos num ou mais partidos, dependendo das suas capacidades para o domínio da língua estrangeira. Na segunda metade do século XVII Domingos Soares é nomeado pela Câmara para exercer o partido da língua dos biscainhos, castelhanos e galegos, falecendo em 1680 é substituído por João Pereira de Castro, sucedendo-lhe em 1681 João Lopes Ribeiro que acumulava funções de corretor e tradutor dos biscainhos ${ }^{2}$.

Estes factos avaliam o grau de intensidade e de maturidade dos contactos que a nível comercial se estabeleciam com a Galiza e que vemos, com escalas e ritmos diferentes, traduzidos em núcleos urbanos como Caminha, Vila-Nova de Cerveira e nas praças militares de Valença e Monção, mais próximas geograficamente. No caso dos Concelhos do Vale do Lima, Ponte de Lima, Ponte da Barca e Arcos de Valdevez, serão as vias terrestres, com particular destaque para a grande via terrestre romana que passava por Ponte de Lima, e o rio Lima, que fun- 
cionavam como o eixo de comunicação das ligações com a Galiza. Estes concelhos eram também pontos de passagem de Sul para Norte, Braga-Monção e pontos de confluência de estradas que facilitavam a circulação das pessoas e das mercadorias em ambos os territórios fronteiriços.

À esta questão da mobilidade transfronteiriça, temos que adicionar outro elemento - o do trajecto peregrinatório compostelano. Os concelhos do Minho Lima e as vias terrestres e fluviais que lhes davam acesso foram desde a época medieval, pontos de passagem obrigatórios dos peregrinos que se deslocavam para Santiago de Compostela. Estes trajectos bem marcados no itinerário do Caminho Português, faziam parte da denominada terceira via, que atravessava o rio Minho, por São Pedro da Torre, local de concentração de peregrinos que vinham de Caminha, Arcos de Valdevez e Ponte de Lima ${ }^{3}$.

A capilaridade de redes de comunicação dos concelhos de fronteira, do Minho-Lima com a Galiza, aportou um outro aspecto de consideração relevante - o estímulo à construção e fixação de um conjunto de infra-estruturas de acolhimento de peregrinos em trânsito, que era proporcionado por uma vasta rede de mosteiros, igrejas, capelas e ermidas, que se define de forma efectiva entre os séculos XV e XVI.

A configuração destes territórios, marcado pela métrica temporal quinhentista, assente sobretudo na expansão Portuguesa, introduzirá uma nova tonificação às economias locais, mormente nas comunidades atlânticas.

A diáspora lusa deixará os seus profundos sinais nestas comunidades dentre os quais, um dos mais evidentes, no norte atlântico português é o surto construtivo encabeçado pela coroa, numa premente necessidade defensiva e de robustecimento das estruturas administrativas e fiscais; pelas estruturas eclesiásticas; pelos movimentos laicais, com destaque para as confrarias; pelo poder municipal e por uma aristocracia local, em busca de afirmação e prestígio social que engrossava as fileiras das instituições laicais de vocação assistencial, desempenhando cargos de prestígio como de provedor, no caso das Misericórdia, ou juiz no caso das confrarias. À margem do anonimato da base da sociedade, estão também os mercadores banqueiros, ricos e poderosos que expiavam as suas penas e agravos, com generosas doações à Igreja. Clientela e dinheiro são para século XVI e $\mathrm{XVII}$ os firmes desígnios que respaldam também, o desenvolvimento artístico que se observou de forma particularmente intensa na região do Alto-Minho, sobretudo na franja atlântica. Esta condição gerará dois fenómenos paralelos: o da oferta e da procura que atrairá mas simultaneamente solicitará mão-de-obra especializada. Este mercado transfronteiriço encontra-se desta forma aberto e beneficiará da especial conjuntura demográfica galega cuja população duplica entre os séculos XVI e primeira metade do século XVIII. Em 1591, a população galega cifra-se em cerca de 630.000 habitantes, em 1752 este número atinge os 1.300 .000 habitantes ${ }^{4}$.

Este factor explicará, segundo Villares, um movimento migratório de grande amplitude que se reflecte por um lado na denominada emigração temporal intra peninsular tendo como destino as regiões de Castela, Andaluzia e Portugal e a emigração definitiva ou de longa duração que se concentrava sobretudo nos centros urbanos do Porto, Lisboa e Madrid. 350.000 galegos, na segunda metade do séc. XVIII, terão saído do seu território para se fixarem de forma mais permanente nestes centros urbanos peninsulares ${ }^{5}$.

A mobilidade de artistas e artífices, para o período da época moderna fez-se sentir de ambos os lados da fronteira, demonstrando que também nesta dimensão, se estabeleciam e se fixavam as relações entre o norte de Portugal e a Galiza. O presente artigo, debruça-se sobre a presença de mestres e oficiais de pedraria galegos que exerceram a sua actividade profissional nos concelhos do vale do Lima, suprindo as necessidades decorrentes do processo de encomenda artísticas.

Este fenómeno é mais amplo que o típico paradigma da emigração galega, a sua análise deve pois, centrarse na existência pré-estabelecida secularmente, de contactos contínuos, regulares e persistentes das comunidades que se fixam nos territórios de fronteira. Para estas comunidades as fronteiras têm contornos esbatidos e nunca se impuseram como barreiras físicas de dimensão política, administrativa e ou militar.

Para os artistas e artífices minhotos e galegos, o espaço transfronteiriço constituía o espaço de trabalho, de possibilidades profissionais mais amplas verificadas sobretudo nos centros urbanos mais dinâmicos. O carácter destas actividades é por norma preciso no tempo, por isso provisório, mas suficientemente expressivo em quantidade e qualidade.

Não poderemos falar propriamente de comunidades organizadas de artistas, mas antes de profissionais do seu ofício que se apresentavam isoladamente ou com as suas pequenas equipes de obreiros. Constata-se ainda o fenómeno de contingentes de obreiros que, de forma mais espontânea, se faziam recrutar para as obras que se executavam nos núcleos urbanos de proximidade. Por contraponto a este movimento identifica-se um outro, mais esparso e pontual, menos documentado ainda, e que se materializa na identificação e escolha deliberada de um determinado profissional por parte do encomendante. Impera pois, nesta dinâmica, a vontade deliberada de quem manda executar e paga a obra. 
Os centros de formação artística, as células de desenvolvimento de oficinas de artistas e artífices de vasta e qualificada experiência estão polarizadas nas dioceses galegas de Tui, Ourense e Santiago, marcadas por um boom artístico inigualável. Estas oficinas supriam a exigente, variada e prolifera demanda construtiva dos poderosos senhores eclesiásticos galegos. Apresentando-se como paradigma deste fenómeno, a Igreja compostelana e os seus arcebispos "mantiveram com firmeza a sua condição não só de senhores espirituais, que ninguém negava, mas também materiais" ${ }^{\text {. }}$

A primazia social que esta nobreza eclesiástica detinha justificará, numa lógica de política de prestígio, a ampla e inigualável diversificada actividade que se fará sentir em todas as artes. Os senhores eclesiásticos galegos são também grandes mecenas.

Em Santiago de Compostela e sob a égide do grande mecenas da catedral, o Arcebispo Frei António Monroy, trabalharam artistas da craveira de Andrade, Frei Gabriel de Casas, Fernando Casas, Miguel de Romay e Garcia de Bouzas que imprimem ao barroco compostelano uma qualidade única que se afere pelos melhores especímenes europeus?

A gigantesca empreitada compostelana é muito mais do que um laboratório de competências desenvolvidas pelos artistas que nela trabalham, marca também um ponto alto de intercâmbio artístico entre o Norte do Portugal e a Galiza, pontualmente documentado por um extenso repertório de nomes de ambos os lados da fronteira.

Para o caso do norte do país, passou-se a percepcionar o fenómeno destas relações artísticas com as províncias galegas de uma forma mais clarividente. Os contactos entre estes territórios vizinhos, no que ao intercâmbio artístico diz respeito, são de longa data, e manifestam-se na arquitectura, na escultura na talha e na pintura. Estudos, ainda que parcelares, apontam para uma certa unidade estética que se apresenta de forma mais evidente na faixa litoral dos dois territórios mas que carece de validação.

Analisando o fenómeno da presença de artistas galegos em território do Alto Minho, a bibliografia mais difundida, trouxe a público alguns dos mais relevantes artistas. Em Caminha, na construção da Matriz daquela Vila, (finais do século XV - primeira metade do século XVI) impuseram-se os nomes dos galegos e biscainhos como João de Castilho, Pero Galego, Tomé de Tolosa e Francisco Fial ${ }^{8}$.

Outros nomes, de artistas e artífices galegos, menos sonantes porque desconhecidos, vão preenchendo o quadro das referências artísticas, deixando as suas marcas na arquitectura, na produção retabular e nas artes da madeira em geral.

Olhando para o panorama geral das obras executadas por artistas e artífices galegos na região do Lima foi possível constatar na pesquisa levada a cabo, que grande parte da mão-de-obra galega era absorvida nas obras de carácter arquitectónico especificamente de encomenda religiosa, se bem que, em casos pontuais, mestres pedreiros galegos são contratados para executar obras de arquitectura civil. No entanto muitas questões ainda se levantam em torno da investigação que falta fazer, no sentido de descortinar de forma mais precisa a expressão e dimensão das obras destes artistas.

Ocorre ainda outra questão relacionada com a análise das fontes primárias: se por um lado é possível identificar o artista, o seu ofício e a sua categoria, outros casos houve em que apenas se afere a actividade, não existindo elementos de identificação, quer do artista ou artífice, quer do ofício e categoria, a documentação apresenta-os com actividade indiferenciada.

\section{Obras de arquitectura religiosa}

\section{Artistas e artífices galegos não identificados}

Tomando como exemplo o núcleo de Viana do Castelo, identificámos, na pesquisa realizada aos arquivos das confrarias da igreja Matriz, contingentes de obreiros galegos, não identificados, assim acontece em 1588 nas obras da construção da sacristia da confraria do Santíssimo Sacramento, da equipe de obreiros, faz parte um oficial galego, não identificado na documentação'.

E em 1746, também na Matriz de Viana do Castelo, nas obras da torre, que a confraria do Espírito Santo construía, adossada ao seu consistório e sacristia, obra projectada pelo Eng. ${ }^{\circ}$ militar Manuel Pinto Vilalobos e executada pelo mestre pedreiro Bento Lourenço, encontramos na conclusão do coruchéu da torre, um aprendiz galego, cujo nome a documentação omite (Fig. 1). ${ }^{10}$

Em Ponte da Barca, as obras que a Misericórdia empreende em 1732, especificamente sacristia, claustro e consistório, são executadas por oficiais de pedreiro galegos, ignoramos o número e uma vez mais o nome ${ }^{11}$. Esta 
mesma instituição declara nas despesas com a obra da capela-mor, que está a executar em 1754, o pagamento de honorários ao a um mestre pedreiro natural do reino da Galiza (Fig. 2) ${ }^{12}$.

Mas se esta realidade apresenta esbatida a intervenção destes oficiais, precisando pouco mais que a data, o encomendante e o local da obra, outros dados permitem com segurança aferir o domínio que os mestres pedreiros galegos detinham do modus operandi dos elaborados processos de arrematação de obras e do potencial mercado para o exercício do seu ofício.

\section{Mestres pedreiros galegos. Dinâmicas construtivas em Ponte da Barca e Arcos de Valdevez}

Como se verá, as confrarias mais prestigiadas e as Misericórdias destacam-se do leque de encomendantes a patrocinar obras nos edifícios que estavam sob sua tutela directa.

As intervenções de carácter arquitectónico com recurso a mestres pedreiros galegos, mais frequentes nestes concelhos do vale do Lima, são essencialmente caracterizadas por obras de raiz e neste pressuposto assume dianteira a construção de igrejas paroquiais, a reformulação de fachadas de templos a par da construção ou reconstrução de unidades físicas como capelas-mor, sacristias ou torres sineiras.

Estas obras eram por norma, publicitadas e reguladas por um complexo quadro de exigências legais que as partes contratantes deviam respeitar integralmente, para além do cumprimento obrigatório do mestre contratado dos apontamentos ou da planta da obra que, finda a sua execução, seria avaliada por peritos do mesmo ofício. Nestes casos em particular, temos documentados mestres de pedraria oriundos da Galiza a responderem aos editais de publicitação de obras, apresentando os seus lances, ao lado de outros mestres da área regional de influência ou até de outras localidades da comarca de Entre Douro e Minho.

Especificamente para as obras de ampliação da capela-mor da igreja do Espírito Santo, em Arcos de Valdevez, os mestres pedreiros galegos Dionísio Salgado e José Pires, apresentam em 1746 os seus lances a par de outros mestres de pedraria de Paredes de Coura, Arcos de Valdevez e Caminha (Fig. 3) ${ }^{13}$.

Ao mestre pedreiro Dionísio Salgado, esta confraria adjudicar em 1748-1749, a obra do paredão do terreiro onde se localizava a Igreja do Espírito Santo ${ }^{14}$.

Esta realidade comprova que de facto, o território da bacia do Lima se apresentava como um efectivo mercado de trabalho para os mestres de pedraria galegos que se lançam na arrematação de obras de escala e envergadura como exemplificaremos seguidamente.

\section{Concelho de Ponte da Barca}

\section{Igreja da freguesia de Britelo}

A escritura de obra da igreja paroquial da freguesia de Britelo datada de 2 de Dezembro de 1726 foi assinada entre o juiz da confraria do Subsino e os mestres pedreiros Francisco e Pedro Gonçalves, naturais de Ponte Vedra, Galiza. Este templo, a construir de raiz, teria de comprimento 66 palmos, de largura 26 e de altura 25 palmos. Levaria um arco cruzeiro e três frestas - duas em cada um dos alçados e uma no frontispício. O contrato incluía duas portas, uma principal e outra travessa e um campanário. Segundo este documento, os mestres pedreiros seguiriam a planta e apontamentos, tendo como modelo, a igreja de Entre Ambos-os-Rios. Por este contrato, os mestres galegos eram ainda obrigados a fabricar o púlpito, cachorros para o coro, nichos para os santos óleos e galhetas e pias de água benta, estavam ainda incumbidos da tarefa de quebrar a pedra para a obra. O valor deste ajuste foi de 97.000 réis, devendo a obra, findar no início de Agosto de 1727, fase em que seria vistoriada por peritos do mesmo ofício.

A obra de pedraria da capela-mor e sacristia desta igreja foi executada igualmente por mestres de pedraria galegos, João Rodrigues e Bento Rodrigues, também naturais de Ponte Vedra. A escritura é assinada a 21 de Março de 1730.

A capela-mor, como determinava a planta, devia ter de comprimento 28 palmos e de largura 20 palmos. Em altura devia corresponder ao corpo da igreja. No alçado nascente seria colocada uma fresta. O ajuste da obra foi feito por preço de 70.000 réis, pagos em três momentos, o primeiro depois de cortada e transportada a pedra para a obra, o segundo no meio e o terceiro no fim da obra, que devia ser concluída em Agosto, no dia de São Lourenço de 1731, submetendo-se posteriormente a vistoria, feita por mestres do ofício, aquilatando do respeito pela planta e apontamentos ${ }^{15}$.

Integrado no vasto conjunto de obras que a Misericórdia de Ponte da Barca leva a cabo na sua igreja, na segunda metade do século XIX, fez parte intervenções no espaço envolvente. O programa de arranjo exterior 
contemplava a construção da Capela do Senhor dos Passos, adjudicada em 1832 a Bento Pires, mestre pedreiro galego. Esta capela que faria parte de um conjunto de pequenos retábulos pétreos da via-sacra estava localizada em frente à sacristia da Misericórdia' ${ }^{16}$.

\section{Igreja da freguesia de Vila Chã}

Os oficiais da confraria do Subsino, da freguesia de Vila Chã adjudicaram em 1812, ao mestre pedreiro Carlos António de Deus, "natural do reino da Galiza" a obra da sua igreja pela quantia de 468.000 réis. Esta obra consistia na demolição da fachada do antigo templo e na construção de uma nova, incluindo uma porta encimada por uma fresta e rematada por uma cruz e quatro pirâmides idênticas à da capela-mor. Os vãos dos alçados laterais (portas e frestas) também seriam intervencionados de forma a corresponderem as medidas de altura e largura.

A demolição da fachada, a remoção dos entulhos, o transporte dos materiais, estadas, cal, areia, grades de ferro, vitrais e redes das três frestas seriam à custa do mestre pedreiro. A execução desta obra devia ser feita de modo a garantir que não fosse alterada a capela do Santíssimo Sacramento ${ }^{17}$.

\section{Concelho de Arcos de Valdevez}

\section{Igreja da freguesia de São Pedro de Vale}

Para a igreja de Nossa Senhora do Vale da freguesia de Vale, Francisco de Araújo e André Cerqueira, Homens Bons, ajustaram a obra do pátio frente ao alçado principal da igreja. Esta escritura de contrato, datada de 21 de Novembro de 1729, indica-nos que o contrato foi assinado com os mestres pedreiros Eugénio da Torre e Inácio Baceiro, naturais de Ponte Vedra, Galiza, assistentes na freguesia de Paço em Arcos de Valdevez ${ }^{18}$.

\section{Igreja Matriz de São Salvador dos Arcos de Valdevez}

Ao serviço da confraria de Santo António da Igreja Matriz dos Arcos de Valdevez, vamos encontrar o mestre pedreiro natural da Galiza, Alberto de Vila Verde, incumbido em 1741 de proceder à colocação das grades e reparação do lajeamento da capela de Santo António. Este mestre pedreiro galego será o autor da obra de pedraria da capela-mor da igreja da freguesia de Padreiro do mesmo concelho dos Arcos de Valdevez, adjudicada por 300.000 réis em 1750. Nesta obra actuou em parceria com o seu conterrâneo, o também mestre pedreiro Miguel de Marcan, natural de Ponte Vedra (Fig. 4) ${ }^{19}$.

\section{Igreja da freguesia de Couto}

O contrato de adjudicação da obra da igreja da freguesia de Couto foi feito em 1747 ao mestre carpinteiro de Ponte da Barca, Tomás de Araújo, por preço de 375.000 réis. Tomás de Araújo sub contratará para a obra de alvenaria, os mestres pedreiros galegos Dionísio Salgado e Jozeph Hereres. A obra deveria ser entregue em finais de Dezembro de 1747 para ser devidamente avaliada ${ }^{20}$.

\section{Igreja paroquial de São Paio}

Na vizinha freguesia de São Paio dos Arcos de Valdevez, situada do outro lado do rio, localiza-se a igreja paroquial com a mesma invocação. Esta igreja paroquial será demolida nos finais do século XVIII por ameaçar ruína, iniciando-se a construção de um novo templo nos finais dessa centúria e inícios da seguinte. "No lugar da Egreja Velha esteve o primeiro templo, que foi demolido há cerca de um século por ameaçar ruina. $\mathrm{O}$ actual foi começado em 1781, e terminou-se em $1831(\ldots)^{\prime 21}$.

Com base na escritura de trespasse, assinada em 1810, obtivemos a informação de que o mestre pedreiro galego Carlos António de Deus arrematou a obra do escadório da igreja pela quantia de 444.000 réis, pretendendo trespassá-la, com todas as cláusulas de obrigação, ao mestre pedreiro João Alves, da freguesia de Gondoriz, Arcos de Valdevez, que se comprometeu a cumprir as determinações contratuais estipuladas no primeiro ajuste ${ }^{22}$.

\section{Igreja Paroquial de Távora (Santa Maria)}

Manuel António Machado, referido na escritura de contrato como senhor da freguesia de Távora (Santa Maria), contrata em 1810, o mestre pedreiro natural da Galiza Ignácio Iglezias para executar a obra da reforma da igreja paroquial ${ }^{23}$. 


\begin{tabular}{|c|c|c|c|}
\hline DATA & ARTISTA & LOCALIDADE & FONTE \\
\hline $\begin{array}{l}1726,22 \text { de } \\
\text { Dezembro }\end{array}$ & $\begin{array}{l}\text { Francisco } \\
\text { Gonçalves } \\
\text { (mestre) }\end{array}$ & $\begin{array}{l}\text { Freguesia de St. } \\
\text { Maria de } \\
\text { Mourente, Ponte } \\
\text { Vedra, Galiza }\end{array}$ & $\begin{array}{l}\text { A.D.V.C., Fundo Notarial de Ponte da Barca, Livro de } \\
\text { Notas, Tabelião: MUHIA, Francisco Cerqueira, } 3^{\circ} \text { Ofício } \\
\text { fls. 200v. - } 202\end{array}$ \\
\hline $\begin{array}{l}1726,22 \text { de } \\
\text { Dezembro }\end{array}$ & $\begin{array}{l}\text { Pedro } \\
\text { Gonçalves } \\
\text { (mestre) }\end{array}$ & $\begin{array}{l}\text { Freguesia de St. }^{a} \\
\text { Maria de } \\
\text { Mourente, Ponte } \\
\text { Vedra, Galiza }\end{array}$ & $\begin{array}{l}\text { A.D.V.C., Fundo Notarial de Ponte da Barca, Livro de } \\
\text { Notas, Tabelião: MUHIA, Francisco Cerqueira, } 3^{\circ} \text { Ofício } \\
\text { fls. } 200 \text { v. }-202\end{array}$ \\
\hline $\begin{array}{l}1727,31 \text { de } \\
\text { Agosto }\end{array}$ & $\begin{array}{l}\text { Inácio } \\
\text { Baceiro } \\
\text { (mestre) }\end{array}$ & $\begin{array}{l}\text { Freguesia de St. }^{\circ} \\
\text { André de Gebe, } \\
\text { Ponte Vedra, } \\
\text { Galiza }\end{array}$ & $\begin{array}{l}\text { A.D.V.C., Fundo Notarial de Arcos de Valdevez, Livro } \\
\text { de Notas, Tabelião: CUNHA, João Alves da, } 2^{\circ} \text { Ofício } \\
\text { fls. } 353 \mathrm{v} .-355 \mathrm{v} \text {. }\end{array}$ \\
\hline $\begin{array}{l}1729,21 \text { de } \\
\text { Novembro }\end{array}$ & $\begin{array}{l}\text { Eugénio } \\
\text { da Torre } \\
\text { (mestre) }\end{array}$ & $\begin{array}{l}\text { Freguesia de St. }^{\circ} \\
\text { André de Gebe, } \\
\text { Ponte Vedra, } \\
\text { Galiza }\end{array}$ & $\begin{array}{l}\text { A.D.V.C., Fundo Notarial de Arcos de Valdevez, Livro } \\
\text { de Notas, Tabelião: CUNHA, João Alves da, } 2^{\circ} \text { Ofício } \\
\text { fls. } 353 \mathrm{v} \text { - }-355 \mathrm{v} \text {. }\end{array}$ \\
\hline $\begin{array}{l}1730,21 \text { de } \\
\text { Março }\end{array}$ & $\begin{array}{l}\text { Bento } \\
\text { Rodrigues } \\
\text { (mestre) }\end{array}$ & $\begin{array}{l}\text { Freguesia de S. } \\
\text { Salvador de } \\
\text { Lérez, Ponte } \\
\text { Vedra, Galiza }\end{array}$ & $\begin{array}{l}\text { A.D.V.C., Fundo Notarial de Ponte da Barca, Livro de } \\
\text { Notas, Tabelião: LEMOS, João de, } 1^{\circ} \text { Ofício fls. } 91 \text { - } \\
\text { 92v. }\end{array}$ \\
\hline $\begin{array}{l}1730,21 \text { de } \\
\text { Março }\end{array}$ & $\begin{array}{l}\text { João } \\
\text { Rodrigues } \\
\text { (mestre) }\end{array}$ & $\begin{array}{l}\text { Freguesia de S. } \\
\text { Salvador de } \\
\text { Lérez, Ponte } \\
\text { Vedra, Galiza }\end{array}$ & $\begin{array}{l}\text { A.D.V.C., Fundo Notarial de Ponte da Barca, Livro de } \\
\text { Notas, Tabelião: LEMOS, João de, } 1^{\circ} \text { Ofício fls. } 91 \text { - } \\
\text { 92v. }\end{array}$ \\
\hline $1744-1745$ & $\begin{array}{l}\text { Alberto de } \\
\text { Vila Verde } \\
\text { (mestre) }\end{array}$ & Galiza & $\begin{array}{l}\text { Arquivo da Igreja Matriz dos Arcos de Valdevez, Livro } \\
\text { da Receita e Despesa, } 1682-1747 \text {, confraria de } \\
\text { Santo António, fls. 132v. - 134v. }\end{array}$ \\
\hline $\begin{array}{l}\text { 1746, } 15 \text { de } \\
\text { Dezembro }\end{array}$ & $\begin{array}{l}\text { Dionisio } \\
\text { Salgado } \\
\text { (mestre) }\end{array}$ & Galiza & $\begin{array}{l}\text { Arquivo da Matriz dos Arcos de Valdevez, Igreja do } \\
\text { Espírito Santo, Documentos Avulsos, confraria do } \\
\text { Espírito Santo, [s. fls.] }\end{array}$ \\
\hline $\begin{array}{l}\text { 1746, } 15 \text { de } \\
\text { Dezembro }\end{array}$ & $\begin{array}{l}\text { José Pires } \\
\text { (mestre) }\end{array}$ & Galiza & $\begin{array}{l}\text { Arquivo da Matriz dos Arcos de Valdevez, Igreja do } \\
\text { Espírito Santo, Documentos Avulsos, confraria do } \\
\text { Espírito Santo, [s. fls.] }\end{array}$ \\
\hline $\begin{array}{l}1761,3 \text { de } \\
\text { Outubro }\end{array}$ & $\begin{array}{l}\text { Angelo } \\
\text { Guiteiro } \\
\text { (mestre) }\end{array}$ & Galiza & $\begin{array}{l}\text { A.D.V.C., Fundo Notarial de Arcos de Valdevez, Livro } \\
\text { de Notas, Tabelião: FARIA, João Durães e COELHO, } \\
\text { Joaquim Inácio, } 2^{\circ} \text { Ofício fls. } 81-82 \mathrm{v} \text {. }\end{array}$ \\
\hline $\begin{array}{l}1761,3 \text { de } \\
\text { Outubro }\end{array}$ & $\begin{array}{l}\text { Francisco } \\
\text { Bento Loureiro } \\
\text { (mestre) }\end{array}$ & Galiza & $\begin{array}{l}\text { A.D.V.C., Fundo Notarial de Arcos de Valdevez, Livro } \\
\text { de Notas, Tabelião: FARIA, João Durães e COELHO, } \\
\text { Joaquim Inácio, } 2^{\circ} \text { Ofício fls. } 81 \text { - } 82 \mathrm{v} \text {. }\end{array}$ \\
\hline
\end{tabular}

Tabela 1. Mestres pedreiros galegos activos em Ponte da Barca e Arcos de Valdevez. 


\begin{tabular}{|c|c|c|c|}
\hline DATA & ARTISTA & LOCALIDADE & FONTE \\
\hline $\begin{array}{l}1810,7 \text { de } \\
\text { Março }\end{array}$ & $\begin{array}{l}\text { Ignácio } \\
\text { Iglezias } \\
\text { (mestre) }\end{array}$ & $\begin{array}{l}\text { Ponte Vedra, } \\
\text { Galiza }\end{array}$ & $\begin{array}{l}\text { A.D.V.C., Fundo Notarial de Arcos de Valdevez, Livro } \\
\text { de Notas, Tabelião: RODRIGUES, António José, } 5^{\circ} \\
\text { Ofício fls. } 11 \mathrm{v} .-13\end{array}$ \\
\hline $\begin{array}{l}1812,16 \text { de } \\
\text { Março }\end{array}$ & $\begin{array}{l}\text { José } \\
\text { Madaleno } \\
\text { (mestre) }\end{array}$ & Galiza & $\begin{array}{l}\text { A.D.V.C., Fundo Notarial de Arcos de Valdevez, Livro } \\
\text { de Notas, Tabelião: LIMA, Caetano José da Silva, } 6^{\circ} \\
\text { Ofício fls. } 104 v .-106\end{array}$ \\
\hline $\begin{array}{l}1829,20 \text { de } \\
\text { Janeiro }\end{array}$ & $\begin{array}{l}\text { Julião Torre } \\
\text { (mestre) }\end{array}$ & $\begin{array}{l}\text { Freguesia de St. } \\
\text { Maria de Mou- } \\
\text { rente, Ponte } \\
\text { Vedra, Galiza }\end{array}$ & $\begin{array}{l}\text { A.D.V.C., Fundo Notarial de Ponte da Barca, Livro de } \\
\text { Notas, Tabelião: MENESES, João Gonçalves, } 4^{\circ} \text { Ofício } \\
\text { fls. } 58-59\end{array}$ \\
\hline $\begin{array}{l}1829,20 \text { de } \\
\text { Julho }\end{array}$ & $\begin{array}{l}\text { Carlos } \\
\text { António de } \\
\text { Deus }\end{array}$ & Galiza & $\begin{array}{l}\text { A.D.V.C., Fundo Notarial de Ponte da Barca, Livro de } \\
\text { Notas, Tabelião: PALHÃO, João António Dias, COSTA, } \\
\text { José Gomes da e MAGALHÃES, João José Soares da } \\
\text { Costa, } 3^{\circ} \text { Ofício fls. } 77-78\end{array}$ \\
\hline $\begin{array}{l}1832,17 \text { de } \\
\text { Setembro }\end{array}$ & $\begin{array}{l}\text { Bento Pires } \\
\text { (mestre) }\end{array}$ & Galiza & $\begin{array}{l}\text { Arquivo da Misericórdia de Ponte da Barca, Livro das } \\
\text { Determinações da Santa Casa da Misericórdia de } \\
\text { Ponte da Barca, 1815, fls. 26-26v }\end{array}$ \\
\hline
\end{tabular}

Tabela 1 (cont.). Mestres pedreiros galegos activos em Ponte da Barca e Arcos de Valdevez.

\section{Igreja paroquial de Aboim}

Na igreja paroquial da freguesia de Aboim, cuja obra de pedraria está datada de 1804, foi construída uma torre em 1825, encomendada pelos Homens Bons da referida freguesia e adjudicada a Joze Magdaleno, que como o documento refere era natural da Galiza e residia nos Arcos de Valdevez ${ }^{24}$.

\section{Igreja da Misericórdia}

Os mestres pedreiros galegos Joze Magdaleno e Carlos de Deus, activos nos Concelhos de Ponte da Barca e Arcos de Valdevez na primeira metade do século XIX, formarão equipa em 1826 para as obras da igreja da Misericórdia de Arcos de Valdevez, especificamente frontispício e adro da igreja (Fig. 5) ${ }^{25}$.

\section{Conclusão}

Com base na documentação levantada compulsámos um conjunto de nomes de mestres pedreiros oriundos da Galiza e activos na bacia do Lima entre 1726 e 1832 (Tab. 1).

A presença de mestre de pedreiros oriundos da Galiza, num período tão lato obriga-nos a reflectir acerca de outra dimensão da problemática artística, a das influências estilísticas que estes mestres pedreiros terão imprimido a estes exemplares arquitectónicos levantando algumas questões de fundo: que traço diferenciado se descortina nestes especímenes de lavra galega? Será possível estabelecer um paralelismo entre as autorias das obras e o carácter inovador, de difícil percepção, que se pode observar em matéria de linguagem ornamental? Estariam estes mestres pedreiros condicionados pelo estrito cumprimento das normas contratuais, isto é o risco e ou apontamentos e pela receita do mecenas? Estes artistas terão imprimido, pese embora algumas condicionantes, a sua assinatura pessoal, alterando o resultado final da obra? Se nalguns casos, parece óbvia a materialização dessa influência, outros há em que essas questões não se verificam.

As respostas a todas estas questões dependem de um árduo e aturado levantamento formal de base territorial, que possibilite comparações rigorosas e cruzamento de fontes capaz de tributar um conhecimento profundo da actividade destes e de outros mestres galegos, das suas obras e do circuito de encomendantes. Só desta forma poderemos abrir pistas sólidas para o estudo e análise da muitas vezes defendida unidade estética na faixa litoral dos dois territórios. 


\section{BIBLIOGRAFIA}

ALVES, Jorge Fernandes, 2002 Imigração de galegos no Norte de Portugal (1500-1900). Algumas notas. In ROEL, Antonio Eiras; LOPO, Domingo Gonzalez (coord.) - Movilidade e migrácions internas na Europa Latina. Unesco. Santiago de Compostela: Universidad (Catedra Unesco), p. 117126.

CARDONA, Paula Cristina Machado, 2004 - A Actividade Mecenática das Confrarias nas Matrizes do Vale do Lima nos Séculos XVII a XIX,

NOTAS

1 Arquivo Histórico Municipal de Viana do Castelo, "Livro dos Acordaons da Câmara 1717-1720" fls. 128-128v:; 130-130v: 135v-136.

2 CARDONA, Paula Cristina Machado, 2004, A Actividade Mecenática das Confrarias nas Matrizes do Vale do Lima nos Séculos XVII a XIX, 4Vols. Porto: Faculdade de Letras da Universidade do Porto. [Tese de doutoramento policopiada], Vol. I. p.53.

${ }^{3}$ GONZÁLES-PAZ, Carlos Andrés, 2009 -La Orden de San Juan de Jerusalém y las Peregrinaciones en la Galicia Medieval (Siglos XII-XIII). In Revista População e Sociedade, $n^{\circ} 17$. Porto: Cepese, p. 12.

${ }^{4}$ VILLARES, Ramon, 1991 - História da Galiza. Lisboa: Livros Horizonte, p. 85.
4Vols. Porto: Faculdade de Letras da ramento policopiada], Vol. I.

GOY, Ana, A Influencia dos modelos de João Lopes o Velho en Terras Galegas nos albores do Barroco. In do Castelo, Câmara Municipal, pp. 137-139.

GONZÁLES-PAZ, Carlos Andrés, 2009 - "La Orden de San Juan de Jerusalém y las Peregrinaciones en la Galicia Medieval (Siglos XII-XIII)". In Revista População e Sociedade, $n^{\circ} 17$. Porto: Cepese, p. 12 Universidade do Porto. [Tese de doutoCadernos vianenses, Tomo 19, Viana

PEREIRA， Esteves, RODRIGUES, Guilherme, 1904 - Portugal Diccionario Historico, Chorográfico, Heraldico, Biographico, Bibliographico, Numismatico e Artistico. Lisboa: ed., João Ramos Torres, p. 683.

VILA JATO, Maria Dolores, 1991 Promotores, Clientes y Talleres en la Galicia Barroca, in Actas do I Congresso Internacional do Barroco, Porto, ed. Reitoria da Universidade do Porto Governo Civil do Porto, II Vol. p. 36.

VILLARES, Ramon, 1991 - História da Galiza. Lisboa: Livros Horizonte, p. 85.

do e José Pires apresentou para a execução da obra respectivamente o preço de 440.000 e 430.000 réis.

${ }^{14}$ Idem, ibidem, p. 774.

${ }^{15}$ Idem, ibidem, pp. 735-736.

${ }^{16}$ Idem, ibidem, p. 703

${ }^{17}$ Idem, ibidem, p. 729

${ }^{18}$ Idem, ibidem, p. 810

${ }^{19}$ Idem, ibidem, p. 810

${ }^{20}$ Idem, ibidem, p. 813

${ }^{21}$ PEREIRA, Esteves, RODRIGUES, ras Galegas nos albores do Barroco. In Cadernos vianenses, Tomo 19, Viana do Castelo, Câmara Municipal, pp. 137-139.

9 CARDONA, Paula Cristina Machado, Ob. cit. p. 167

${ }^{10}$ Idem, ibidem, p. 132.

${ }^{11}$ Idem, ibidem, p. 692.

${ }^{12}$ Idem, ibidem, p. 694.

${ }^{13}$ Idem, ibidem, p. 769. Os mestres pedreiros galegos Dionísio Salga-

Guilherme, 1904 - Portugal Diccionario Historico, Chorográfico, Heraldico, Biographico, Bibliographico, Numismatico e Artistico. Lisboa: ed., João Ramos Torres, p. 683.

22 CARDONA, Paula Cristina Machado, Ob. cit. p. 792

${ }^{23}$ Idem, ibidem, p. 807

${ }^{24}$ Idem, ibidem, p. 821.

${ }^{25}$ Idem, ibidem, p. 529. 